Eficacia de agua

y jabón y de

preparaciones

basadas en alcohol

contra el virus de

la influenza $\mathrm{A}$

(H1N1) en manos

del personal de

salud voluntario.

Efficacy of soap and

water and alcohol-

based hand-rub

preparations against

live H1N1 influenza

virus on the hands of

human volunteers.

Grayson $M L$,

Melvani Sh, Druce

$J$, Barr I, Ballard S,

Johnson P, et al.

Clin Infect Dis

2009; 48: 285-91.
A pesar de que la transmisión persona-persona del virus de la influenza se produce principalmente por diseminación de gotitas, la transmisión por medio de las manos de los pacientes y el personal de salud es también potencialmente importante. Una higiene de manos apropiada debería reducir el riesgo de transmisión. Debido a la reciente preocupación por la influenza aviar y la potencial aparición de una pandemia de influenza, este estudio se planteó como objetivo clarificar estas dudas por medio de la evaluación de la eficacia de distintos protocolos de higiene de manos, usando como voluntarios a personal de salud, quienes fueron expuestos en forma cutánea y bajo condiciones controladas al virus vivo de influenza A (H1N1). Estudio prospectivo (2005 y 2006), observacional realizado en el laboratorio de referencia de enfermedades infecciosas y en el centro de colaboración para influenza de la OMS en Australia. Los voluntarios habían recibido en el 2005 la vacuna de influenza $\left(\right.$ Fluvax $\left.^{\circledR}\right)$ y tenían niveles adecuados de anticuerpos contra este virus. Veinticuatro horas previas al inicio del estudio, estas personas debieron suspender el uso de cualquier tipo de productos medicados para higiene de manos, cremas, shampoo o baños en piscinas (cloro). Sus manos fueron inspeccionadas cuidadosamente en busca de dermatitis, heridas o cualquier problema de la piel y quienes lo presentaban fueron excluidos hasta que sus manos estuvieran indemnes. Todos fueron instruidos en el correcto uso de los protocolos de higiene de manos y usaron mascarilla de alta filtración (N95), gorro y delantal de manga larga en cada procedimiento. En el estudio se evaluó la eficacia de la higiene de manos y en una parte de los sujetos se evaluó la viabilidad del virus H1N1. Se les aseguró un stock adecuado de oseltamivir para tratar a los participantes en caso de que iniciaran signos clínicos de la enfermedad. Todas las pruebas fueron realizadas en salas de aislamientos con presión negativa y en laboratorios que cumplían con las medidas de seguridad.

A los voluntarios se les contaminó las manos con 1 $\mathrm{ml}$ de $\sim 1,8 \times 10^{7}$ dosis infectante tisular (TCID) $)_{50} / 0,1 \mathrm{~mL}$ de virus vivo de influenza A/New Caledonia/20/99 (H1N1) antes de realizar alguno de los cinco protocolos de higiene de manos definidos: agua y jabón; etanol gel a 61,5\%; etanol $70 \%$ más clorhexidina 0,5\%; isopropanol $70 \%$ más clorhexidina 0,5\% y $\sin$ higiene de manos. La concentración de H1N1 en manos antes/después de la higiene se determinó por cultivo viral y RPC-TR en tiempo real. Además se evaluó la viabilidad del virus en las manos por más de 60 minutos sin higiene de manos de por medio.

Resultados: En 14/20 participantes se identificó una disminución significativa en los títulos virales luego de un corto periodo de secado de manos con aire. En 6/ 20 no se detectó el virus en las manos después de un corto periodo de secado con aire (sin higiene de manos). Los cultivos virales demostraron que las cuatro alternativas de higiene de manos erradicaron A (H1N1) en 14/14 manos del personal. La RPC sugirió que la higiene con agua y jabón fuera significativamente mejor que las tres alternativas en que se usó alcohol; sin embargo, la diferencia fue mínima (1-100 copias/ $\mu$ de virus). Además demostró que existe una mínima reducción del virus luego de 60 minutos sin higiene de manos.

Conclusión: Los autores concluyeron que la higiene de manos con agua y jabón o soluciones basadas en alcohol resultan altamente efectivas en la reducción del virus de influenza A (H1N1). Por lo tanto, una higiene de manos apropiada puede ser una importante iniciativa de Salud Pública para reducir la transmisión de epidemias o pandemias de influenza.

Alejandra Zambrano G. y Ma. Irene Jemenao P. Comité Infecciones Intrahospitalarias SOCHINF

\title{
Fe de erratas
}

En el artículo: "Pericarditis por Mycobacterium tuberculosis multiresistente en un paciente con infección por VIH. Reporte de un caso clínico y revisión de la literatura" (Rev Chil Infect 2009; 26 (2); 156-61, se incluyó en pág. 157 una foto de radiografía de tórax que no corresponde al caso publicado.

En el artículo: "Normas de manejo y tratamiento de las Infecciones de Transmisión Sexual (ITS). Primera Parte”. Rev Chil Infect 2009; 26 (2): 174-90, en pág 179, columna izquierda, línea 41,

Dice: "un leve aumento en relación al 2005 (0,22 y 0,18 por cada 1.000 nacidos vivos corregidos (NVC), respectivamente".

Debe decir: "un leve aumento en relación al 2005 (0,22 y 0,18 por cada 1.000 nacidos vivos conocidos (NVC), respectivamente". 